\title{
Polish Endogonaceae 2. Acaulospora rugosa, Glomus aggregatum, Glomus etunicatum, Glomus fasciculatum and Glomus occultum
}

\author{
JANUSZ BŁASZKOWSKI
}

\begin{abstract}
BLASZKOWSKI, J. 1990: Polish Endogonaceae 2. Acaulospora rugosa, Glomus aggregatum, Glomus etunicatum, Glomus fasciculatum and Glomus occultum. - Karstenia 30:1-13.

The Polish occurrence and distribution are described and illustrated for five species of the Endogonaceae. Glomus fasciculatum (Thaxter) Gerd. \& Trappe emend. Walker \& Koske has frequent occurrences throughout the country. Glomus aggregatum Schenck \& Smith emend. Koske, G. etunicatum Becker \& Gerd. and G. occulium Walker probably occur in the whole of Poland as well, although with lower frequencies. All four species were found among both cultivated and natural plants. Acaulospora rugosa Morton was isolated from only 1 of the 152 soil samples studied. The species is new to Europe, having earlier been known only from West Virginia.
\end{abstract}

Key words: Acaulospora, Endogonaceae, Glomus, occurrence in Poland, taxonomy

Janusz Błaszkowski, Department of Plant Pathology, Academy of Agriculture, Slowackiego 17, PL-71434 Szczecin, Poland

\section{Acaulospora rugosa Morton}

The spores from Poland (Figs. 1-4) do not differ from those described by Morton (1986). They are pale yellow (2.5Y 8/6, Munsell Color Company, INC., Baltimore, Maryland 1954), globose to subglobose, (70-)80(-120) $\mu \mathrm{m}$ in diam, sometimes ovoid, $70 \times 120 \mu \mathrm{m}$. The spore wall consists of five walls (walls 1-5) in three groups (groups A, B, C). Group A consists of a hyaline, membranous, (0.7-) $0.9(-1.2) \mu \mathrm{m}$ thick outermost wall (wall 1) and of a pale yellow (2.5Y 8/6), laminate, (2.4-) 3.1 (3.8) $\mu \mathrm{m}$ thick inner wall (wall 2). Group B consists of a hyaline, unit, $(0.5-) 0.7(-1.2) \mu \mathrm{m}$ thick wall (wall 3). Group $\mathrm{C}$ consists of a hyaline, membranous, beaded, $\pm 0.5 \mu \mathrm{m}$ thick wall (wall 4), adhering to a hyaline, amorphous, (0.9-)1.1(-2.0) $\mu \mathrm{m}$ thick innermost wall (wall 5).

This species has been known only from West Virginia.

In Poland A. rugosa was found in only one soil sample, taken from under Calamagrostis arundinacea (L.) Roth in a forest (Table 1, Fig. 22). Its spore density and the relative density (the number of spores of $A$. rugosa as a percentage of the total spores in a soil sample) was 39 per $100 \mathrm{~g}$ dry soil and $10.9 \%$, respectively.

\section{Material examined}

See Table 1; specimens deposited: 720-746, 1049-1053 (DPP). 
Table 1. Frequency of occurrence of Acaulospora rugosa in Poland and chemical properties of the soil from which this species was isolated.

\begin{tabular}{|c|c|c|c|c|c|c|c|}
\hline \multirow{2}{*}{\multicolumn{2}{|c|}{ Plant family Plant species }} & \multirow{2}{*}{$\begin{array}{l}\text { No. of soil sample } \\
\text { (see Fig. 22) }\end{array}$} & \multirow{2}{*}{$\begin{array}{l}\text { No. of spores/ } \\
100 \mathrm{~g} \text { dry soil }\end{array}$} & \multicolumn{4}{|c|}{ Chemical properties } \\
\hline & & & & $\underset{\text { (in } \mathrm{H}_{2} \mathrm{O} \text { ) }}{\mathrm{pH}}$ & $\mathrm{No}_{3}$ & $\begin{array}{l}\mathrm{P}_{2} \mathrm{O}_{5} \\
(\mathrm{mg} \mathrm{kg}\end{array}$ & $\mathrm{K}_{2} \mathrm{~K}_{2} \mathrm{O}$ \\
\hline Gramineae & Calamagrostis arundinacea & 89 & 39 & 4.8 & 21 & 16 & 14 \\
\hline
\end{tabular}

Glomus aggregatum Schenck \& Smith emend. Koske

G. aggregatum is one of the species of the G. fasciculatum complex, from which $G$. deserticola Trappe, Bloss \& Menge and $G$. hoi Berch \& Trappe have also been separated. It is distinguishable from other species by its small, smooth, thin-walled spores of various shapes, which are pale yellow to yellowbrown, generally have an open pore of a subtending hypha, and possess (mature spores) one or two thin walls. The most characteristic feature, however, is the production of spores by internal proliferation (Koske 1985).

The Polish specimens possess all the features mentioned above (Figs. 5-10). The spores occurred both singly in the soil and in sporocarps. Those isolated singly from the soil most often contain internal proliferations. The spores in sporocarps are usually 1-walled, although spores with 2 walls and with internal proliferations occur as well (Figs. 5-7). The walls of 1- and 2-walled spores are usually coloured and laminate, although their inner wall is sometimes hyaline and very thin, resembling a membranous wall. The hyphae of $G$. aggregatum sporocarps often possess internal hyphae or double walls (Figs. 10) similar to those described and illustrated by Koske (1985).

G. aggregatum was originally described on the basis of spores found in a citrus nursery in Florida (Schenck \& Smith 1982). Koske $(1985,1987)$ and Sylvia (1986) considered it to be common in maritime sand dunes of the U.S. and Canada. Zak et al. (1982) found it to be one of the most common vesicular-arbuscular mycorrhizal fungi associated with Agropyron trachycaulum (Link) Malte. on two mine spoils, and Dalpé et al. (1986) often isolated this species from an apple orchard. Bloss and Walker (1987) found G. aggregatum spores among roots of Agave spp. and Trifolium repens L. in the Santa Catalina Mountains in Arizona.
In Poland G. aggregatum was found in 25 soil samples (Table 2, Fig. 22). Only three of them (nos. $93,123,128$ ) come from maritime dunes, five (nos. $25,37,38,48,113$ ) from soils adjacent to them, six from forest soils, and the others from other cultivated and natural localities. The spore densities and the relative densities of this species ranged from 1 to 116 per $100 \mathrm{~g}$ dry soil and from 0.5 to $42.8 \%(\overline{\mathbf{x}}=$ $6.3 \%)$, respectively. No significant correlation was observed between the spore densities and the chemical properties of the soils examined. The species is new to Poland.

\section{Material examined}

See Table 2; specimens deposited: 292-303 (DPP).

\section{Glomus etunicatum Becker \& Gerd.}

G. etunicatum is a very confusing species because of its inconstant spore wall structure. Among the specimens from Poland are spores with a fuily developed wall (2-walled with an outer evanescent wall and an inner laminate wall) as well as spores without the outer wall, which easily sloughs (Figs. 11-14). Other features, such as the presence of a thin-walled and fragile subtending hypha, and the dimensions and colour of the spores, agree with the original description by Becker and Gerdemann (1977).

G. etunicatum is probably globally widespread, although its occurrence has formally been recorded only in the U.S. (e.g. Becker \& Gerdemann 1977, Schenck \& Smith 1981, Hetrick \& Bloom 1983, Miller et al. 1985, Bloss \& Walker 1987) and Canada (Dalpé et al. 1986).

In Poland G. etunicatum was found in only 4 soil samples, taken from under cultivated and natural plants (Table 3, Fig. 23). Its spore density was relatively high (30 per $100 \mathrm{~g}$ dry soil) only in sample no. 91 , ranging from 2 to 6 per $100 \mathrm{~g}$ dry soil in the 

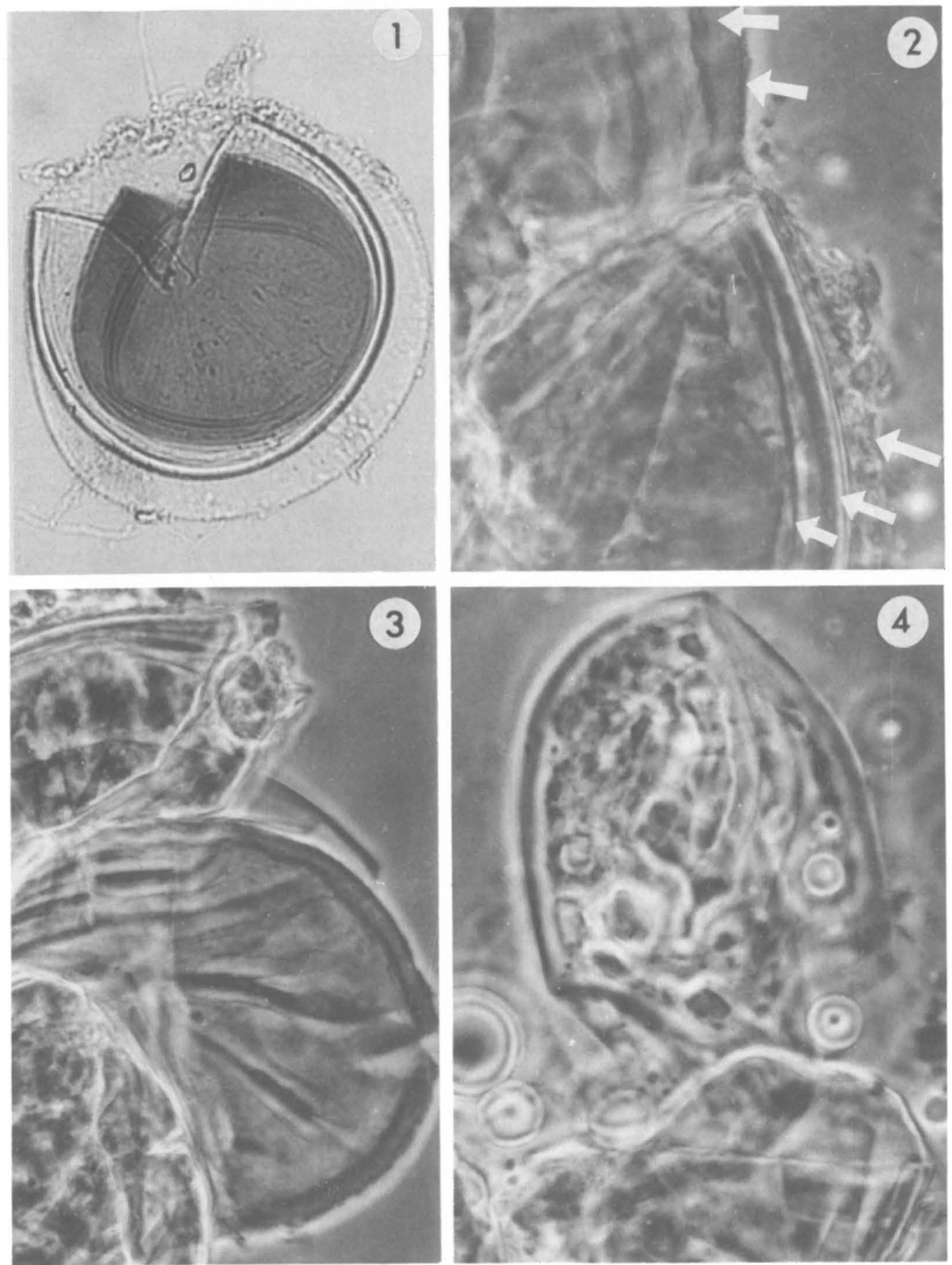

Figs. 1-4. Acaulospora rugosa. - 1: A crushed spore in Melzer's reagent with lactic acid, showing the swollen outermost wall and the innermost one stained dark, $\times 520$. $-2: 5$ walls of a spore are visible, phase contrast (PC), $\times 1200$. -3 : Another crushed spore showing the spore wall structure, PC, $\times 645$. - 4: The amorphous nature of the innermost wall is evident, PC, $\times 900$. 

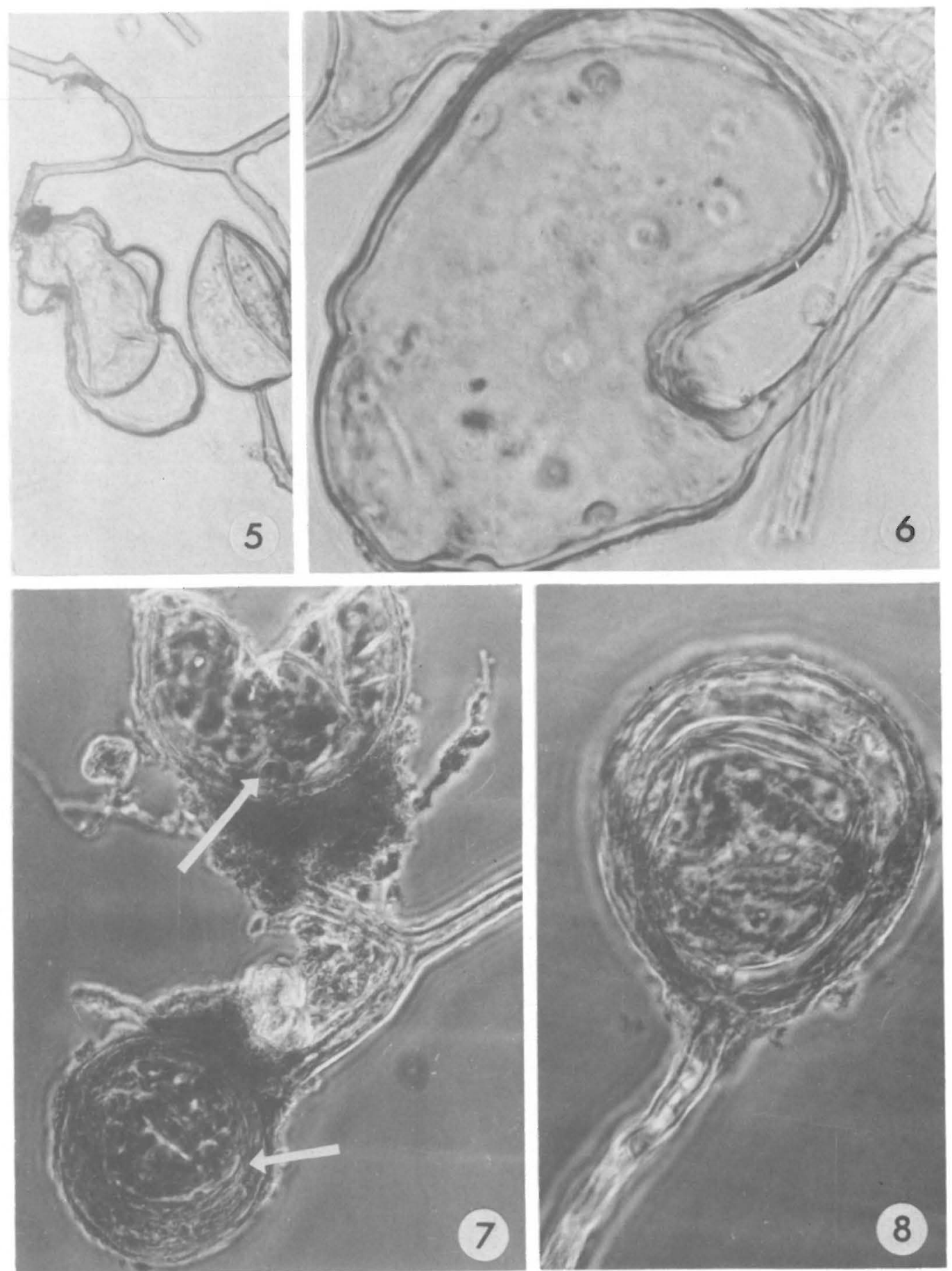

Figs. 5-8. Glomus aggregatum. - 5: A fragment of a sporocarp with the 1-walled spore and the inner spore formed by internal proliferation from the subtending hypha, $\times 347$. $-6:$ A spore from the same sporocarp showing the funnel-shaped subtending hypha, $x 1084$. - 7: Two spores with inner proliferations of different developmental degrees (arrows), PC, $\times 360$. - 8: A spore with the fully formed inner spore, $\mathrm{PC}, \times 530$. 

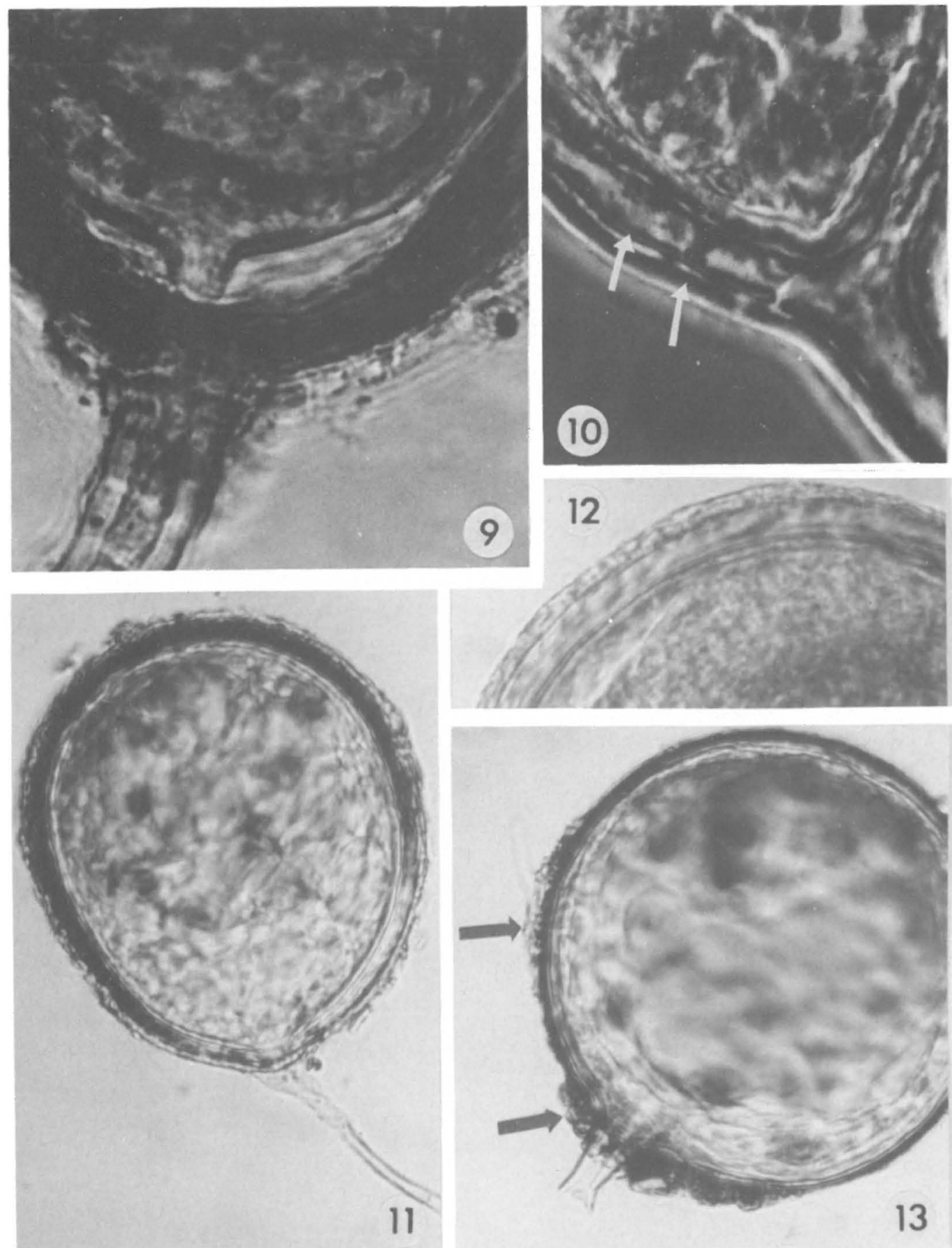

Figs. 9-13. - 9-10. Glomus aggregatum. - 9: The same spore as in Fig. 8 showing the inner spore proliferating from the subtending hypha of the mother spore, $x 1550$. - 10: Hyphae with the outer and inner hyphal walls (arrows), PC, x $1530 .-11-13$. Glomus etunicatum. - 11: An intact spore with fully developed walls, $\times 590 .-12$ : The inconstant nature of the outer wall can be observed, $\times 638$. -13 : Only fragments of the outer wall can be seen (arrows); the hyaline subtending hypha is visible, $\times 600$. 

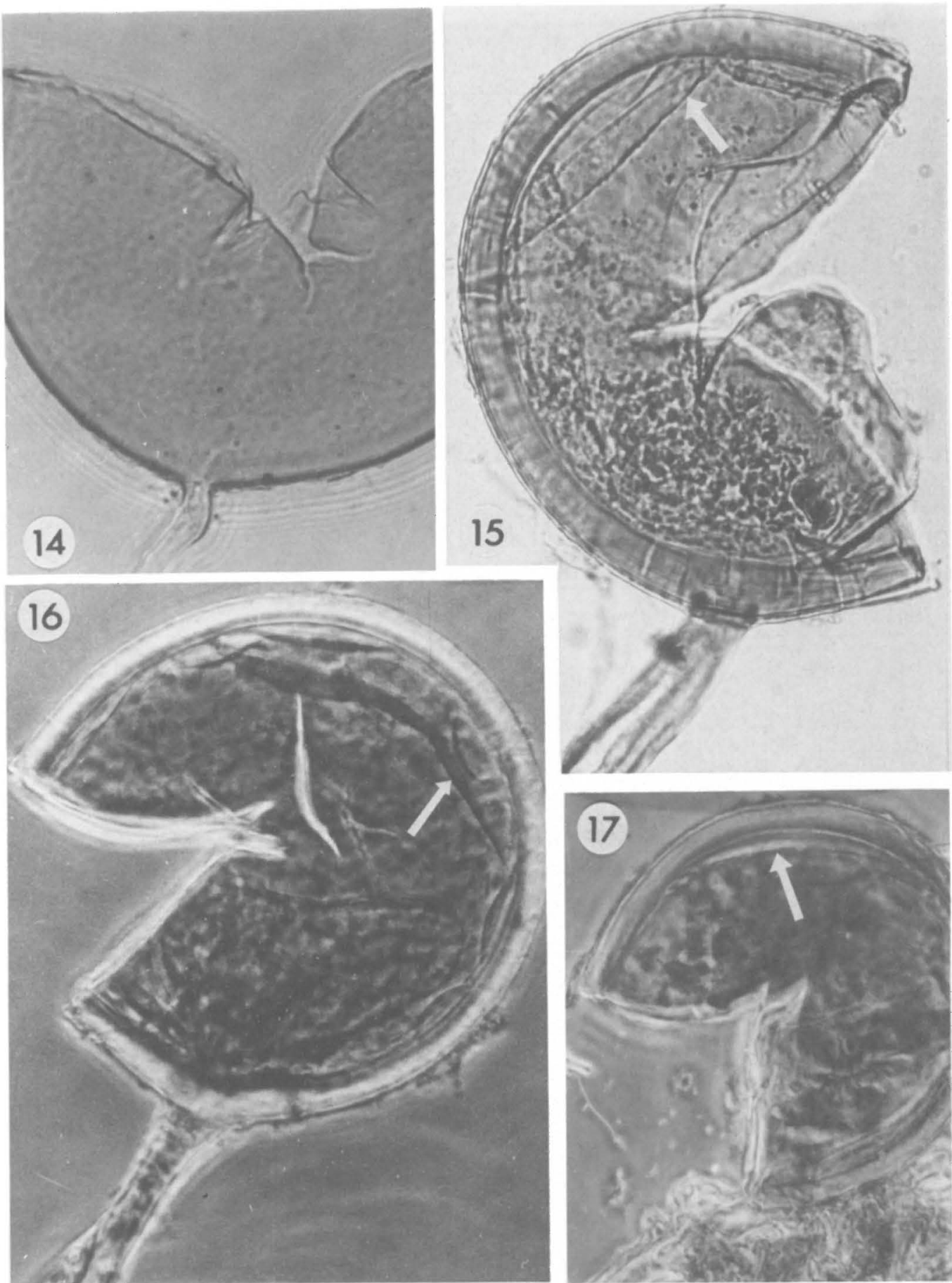

Figs. 14-17. - 14. Glomus etunicatum, a crushed spore without its outer wall, which has been completely sloughed, $x$ 533. 15-17. Glomus fasciculatum. - 15: A crushed spore with 3 walls; the innermost wall is marked (arrow), $\times 680$. -16 : The wrinkling innermost wall can be seen (arrow), PC, $\times 770$. - 17: A crushed spore from a sporocarp; the innermost wall (arrow) is separated from the middle wall, PC, $\times 548$. 

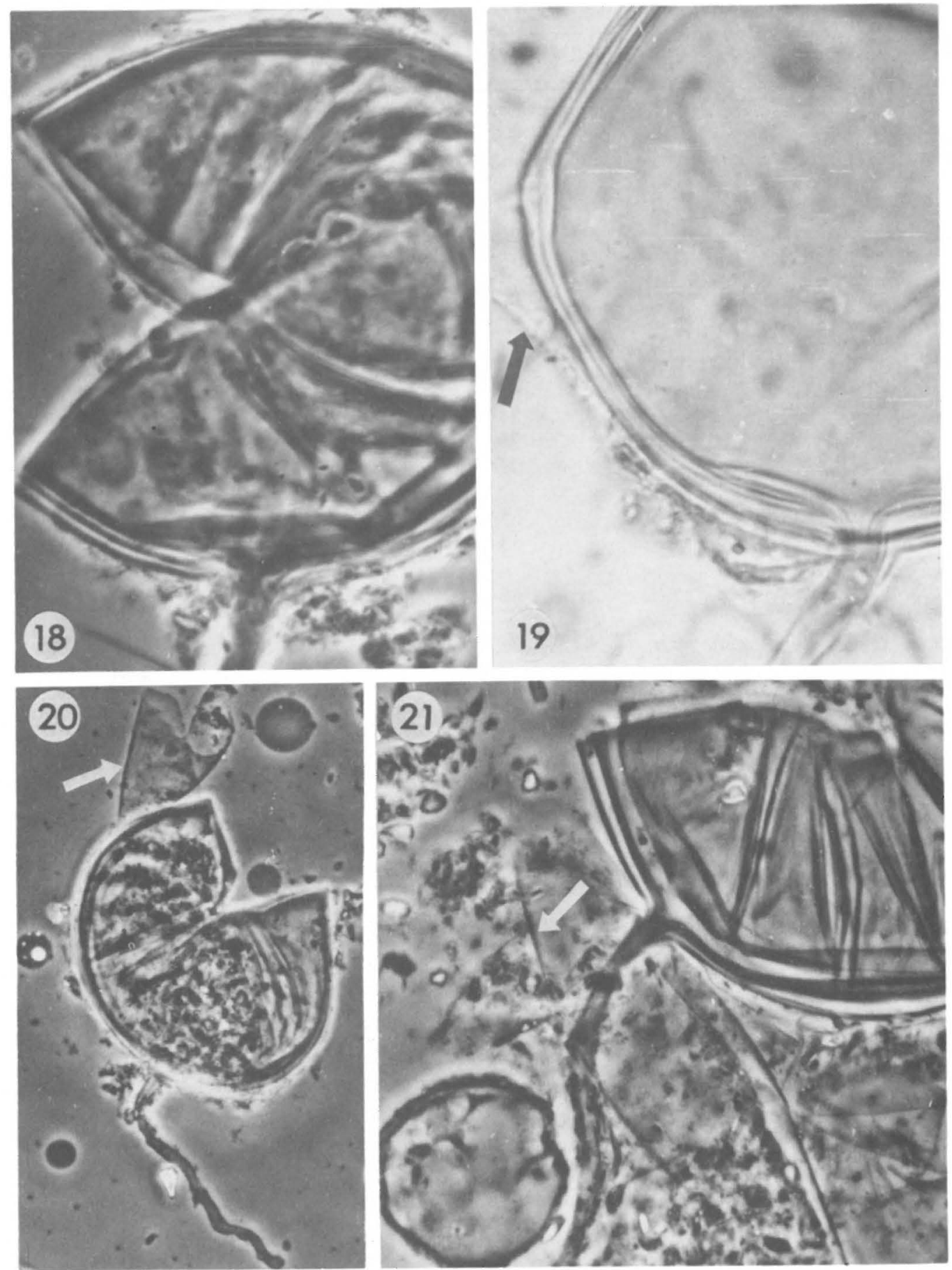

Figs. 18-21. Glomus occultum. - 18: A crushed spore with 3 walls separated near the subtending hypha, PC, $\times 1100$. - The 3walled spore wall structure with the additional layer of debris (arrow) can be seen, $x 1030 .-20$ and 21: Two spores with the additional unit-like wall (arrows), PC, x 550 and 890, respectively. 
Table 2. Frequency of occurrence of Glomus aggregatum in Poland and chemical properties of soils from which this species was isolated.

\begin{tabular}{|c|c|c|c|c|c|c|c|}
\hline \multirow{3}{*}{$\begin{array}{l}\text { Plant family } \\
\text { Cupressaceae }\end{array}$} & \multirow{3}{*}{$\begin{array}{l}\text { Plant species } \\
\text { Thuja occidentalis }\end{array}$} & \multirow{3}{*}{$\begin{array}{l}\text { No. of soil sample } \\
\text { (see Fig. 22) } \\
37,90,116\end{array}$} & \multirow{3}{*}{$\begin{array}{l}\text { No. of spores/ } \\
100 \mathrm{~g} \text { dry soil } \\
6,1,10\end{array}$} & \multirow{2}{*}{\multicolumn{4}{|c|}{ 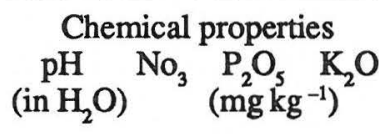 }} \\
\hline & & & & & & & \\
\hline & & & & $\begin{array}{l}4.5- \\
6.6\end{array}$ & $\begin{array}{r}34 \\
260\end{array}$ & $\begin{array}{c}6- \\
10\end{array}$ & $\begin{array}{r}9 \\
209\end{array}$ \\
\hline \multirow[t]{10}{*}{ Gramineae } & Avena sativa & 25 & 1 & 6.3 & 40 & 31 & 27 \\
\hline & Festuca polesica & 75 & 1 & 4.8 & 20 & 15 & 17 \\
\hline & Festuca rubra & 73 & 116 & 5.6 & 16 & 13 & 13 \\
\hline & & 88 & 8 & 6.1 & 20 & 17 & 16 \\
\hline & Poa pratensis & 95 & 5 & 5.1 & 17 & 16 & 18 \\
\hline & Triticum vulgare & 107 & 1 & 5.2 & 30 & 14 & 10 \\
\hline & & 148 & 1 & 6.0 & 50 & 114 & 161 \\
\hline & Zea mays & 38 & 3 & 5.6 & 72 & 19 & 17 \\
\hline & & 91 & 1 & 6.5 & 80 & 23 & 25 \\
\hline & Unknown grass & 99 & 13 & 5.1 & 10 & 14 & 9 \\
\hline \multirow[t]{2}{*}{ Leguminosae } & Lupinus luteus & 69 & 26 & 6.4 & 83 & 64 & 60 \\
\hline & Phaseolus vulgaris & 48 & 16 & 6.7 & 71 & 57 & 62 \\
\hline Liliaceae & Allium porrum & 41 & 2 & 5.9 & 38 & 24 & 28 \\
\hline \multirow[t]{4}{*}{ Rosaceae } & Crataegus monogyna & $113,121,140$ & $1,4,3$ & $\begin{array}{l}5.2- \\
6.2\end{array}$ & $\begin{array}{r}35- \\
160\end{array}$ & $\begin{array}{l}22- \\
35\end{array}$ & $\begin{array}{l}25- \\
30\end{array}$ \\
\hline & Fragaria vesca & 42 & 2 & 4.3 & 48 & 14 & 21 \\
\hline & Prunus domestica & 74 & 3 & 5.2 & 24 & 18 & 17 \\
\hline & Rosa canina & $93,123,12 \hat{\imath}$ & $4,8,30$ & $\begin{array}{l}3.8- \\
4.5\end{array}$ & $\begin{array}{l}20- \\
38\end{array}$ & $\begin{array}{c}6 \\
18\end{array}$ & $\begin{array}{l}14 \\
17\end{array}$ \\
\hline Umbelliferae & Anthriscus sylvestris & 71 & 3 & 4.1 & 51 & 12 & 21 \\
\hline
\end{tabular}

other samples. The relative density of this species ranged from 0.4 to $13.9 \%(\bar{x}=6.2 \%)$. These are the first finds of G. etunicatum in Poland.

\section{Material examined}

See Table 3; specimens deposited: 539-550 (DPP).

Glomus fasciculatum (Thaxter) Gerd. \& Trappe emend. Walker \& Koske

The Polish collections (Figs. 15-17) conform well with the emended description by Walker and Koske (1987), although the innermost wall of the spores from Poland (a membranous wall) rarely stains in Melzer's reagent. Most of the collections studied were preserved in lactophenol, in which spores usually lose their ability to react to this reagent (Morton 1986 ), which is probably the reason for this divergence.

According to Walker and Koske (1987), G. fasciculatum is one of the species of the Endogonaceae most often recorded in soil surveys and most often cited as used in studies of plant growth responses. These authors stated that it is frequently confused with other species, especially $G$. aggregatum, $G$. deserticola, G. invermaium Hall, G. fuegianum (Speg.) Trappe \& Gerd., G. occultum Walker and Sclerocystis rubiformis Gerd. \& Trappe, and that at present it is impossible to determine its real distribution in the world.

Although the occurrence of $G$. fasciculatum had already been treated in Poland (Błaszkowski 1989), I 


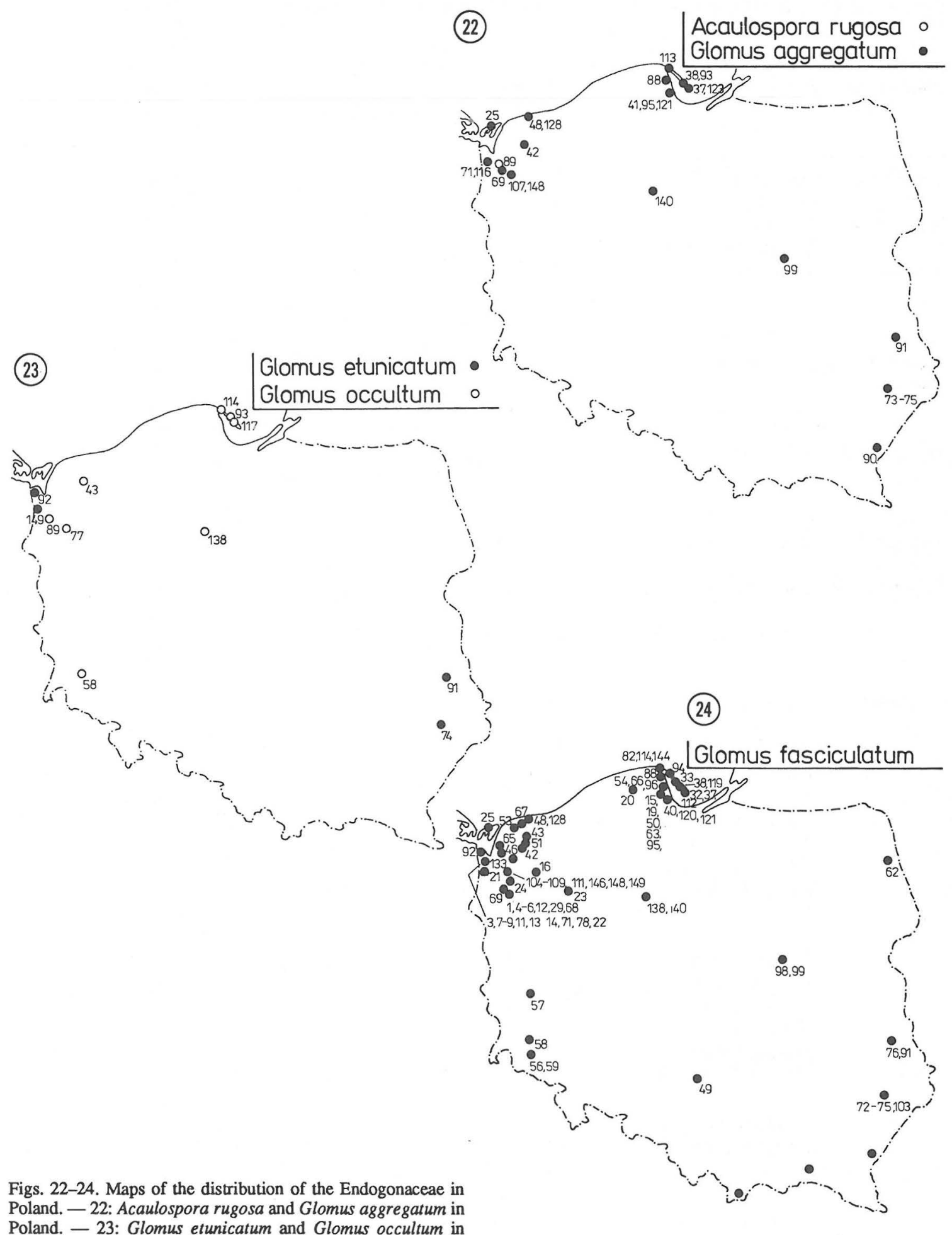

Poland.

Poland. - 24: Glomus fasciculatum in Poland. 
Table 3. Frequency of occurrence of Glomus etunicatum in Poland and chemical properties of soils from which this species was isolated.

\begin{tabular}{|c|c|c|c|c|c|c|c|}
\hline \multirow{3}{*}{$\begin{array}{l}\text { Plant family } \\
\text { Gramineae }\end{array}$} & \multirow{3}{*}{$\begin{array}{l}\text { Plant species } \\
\text { Triticum vulgare }\end{array}$} & \multirow{3}{*}{$\begin{array}{c}\text { No. of soil sample } \\
\text { (see Fig. 23) } \\
149\end{array}$} & \multirow{3}{*}{$\begin{array}{c}\text { No. of spores/ } \\
100 \text { g dry soil } \\
2\end{array}$} & \multirow{2}{*}{\multicolumn{4}{|c|}{ 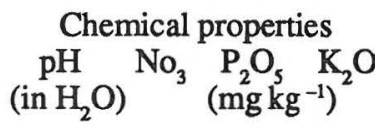 }} \\
\hline & & & & & & & \\
\hline & & & & 6.2 & 56 & 113 & 160 \\
\hline & Zea mays & 91 & 30 & 5.6 & 72 & 19 & 17 \\
\hline \multirow[t]{2}{*}{ Rosaceae } & Malus domestica & 92 & 4 & 5.7 & 74 & 26 & 12 \\
\hline & Prunus domestica & 74 & 6 & 5.2 & 24 & 18 & 17 \\
\hline
\end{tabular}

Table 4. Frequency of occurrence of Glomus fasciculatum in Poland and chemical properties of soils from which this species was isolated.

\begin{tabular}{|c|c|c|c|c|c|c|c|}
\hline \multirow{3}{*}{$\begin{array}{l}\text { Plant family } \\
\text { Aceraceae }\end{array}$} & \multirow{3}{*}{$\begin{array}{l}\text { Plant species } \\
\text { Acer palmatum }\end{array}$} & \multirow{3}{*}{$\begin{array}{l}\begin{array}{l}\text { No. of soil sample } \\
\text { (see Fig. 24) }\end{array} \\
29\end{array}$} & \multirow{3}{*}{$\begin{array}{c}\text { No. of spores/ } \\
100 \mathrm{~g} \text { dry soil } \\
110\end{array}$} & \multirow{2}{*}{\multicolumn{4}{|c|}{\begin{tabular}{c}
\multicolumn{3}{c}{ Chemical properties } \\
$\underset{\left.\text { (in } \mathrm{H}_{2} \mathrm{O}\right)}{\mathrm{N}} \mathrm{No}_{3} \underset{\left(\mathrm{mg} \mathrm{kg}^{-1}\right)}{\mathrm{P}_{2} \mathrm{O}_{5}}$
\end{tabular}}} \\
\hline & & & & & & & \\
\hline & & & & 5.8 & 34 & 22 & 20 \\
\hline \multirow[t]{3}{*}{ Cupressaceae } & \multirow[t]{2}{*}{ Juniperus communis } & 98 & 38 & 5.1 & 10 & 14 & 9 \\
\hline & & 144 & 7 & 5.2 & 27 & 15 & 24 \\
\hline & \multirow[t]{2}{*}{ Thuja occidentalis } & $4,37,90,102$ & $21,155,12,12$ & $4.5-$ & $20-$ & $10-$ & 9 \\
\hline & & & & & & & \\
\hline Geraniaceae & Geranium sp. & 3 & 7 & 6.5 & 40 & 35 & 45 \\
\hline \multirow[t]{20}{*}{ Gramineae } & Avena sativa & 25 & 11 & 6.3 & 40 & 31 & 27 \\
\hline & \multirow[t]{2}{*}{ Calamagrostis arundinace } & 76 & 20 & 5.8 & 28 & 24 & 30 \\
\hline & & 78 & 10 & 4.0 & 68 & 6 & 5 \\
\hline & Corynephorus canescens & 32 & 1 & 6.1 & 34 & 30 & 39 \\
\hline & Festuca ovina & 50 & 52 & 5.1 & 31 & 25 & 28 \\
\hline & Festuca polesica & 75 & 86 & 4.8 & 20 & 15 & 17 \\
\hline & \multirow[t]{2}{*}{ Festuca rubra } & 73 & 35 & 5.8 & 32 & 21 & 19 \\
\hline & & 88 & 48 & 5.9 & 35 & 25 & 32 \\
\hline & Festuca sp. & 49 & 6 & 5.1 & 35 & 30 & 34 \\
\hline & Hordeum vulgare & 24 & 5 & 6.3 & 35 & 32 & 40 \\
\hline & Lolium multiflorum & 82 & 170 & 5.7 & 35 & 34 & 30 \\
\hline & Poa pratensis & 95 & 23 & 5.1 & 17 & 16 & 18 \\
\hline & Secale cereale & 65 & 35 & 5.8 & 38 & 27 & 30 \\
\hline & Setaria italica & 13 & 17 & 6.4 & 40 & 35 & 38 \\
\hline & \multirow[t]{2}{*}{ Sorghum sudanense } & 8 & 24 & 7.0 & 61 & 24 & 41 \\
\hline & & 11 & 12 & 6.6 & 45 & 29 & 40 \\
\hline & Triticum aestivum & 58 & 689 & 6.7 & 71 & 24 & 28 \\
\hline & Triticum vulgare & $21,62,104-109$, & $2,6,190,352,20$ & $5.2-$ & 26 & $6-$ & 4 \\
\hline & & $\begin{array}{c}111,145,146 \\
148,149\end{array}$ & $\begin{array}{c}45,78,27,13,2 \\
1,1,1\end{array}$ & 6.6 & 61 & 114 & 161 \\
\hline & Zea mays & $38,40,46,56$ & $78,1,3,1,8$ & $5.6-$ & $31-$ & 19 & 17- \\
\hline
\end{tabular}


Table 4. Contnd.

\begin{tabular}{|c|c|c|c|c|c|c|c|}
\hline \multirow[t]{3}{*}{ Plant family } & \multirow{3}{*}{$\begin{array}{l}\text { Plant species } \\
\text { Unknown grass }\end{array}$} & \multirow{3}{*}{$\begin{array}{c}\begin{array}{c}\text { No. of soil sample } \\
\text { (see Fig. 24) } \\
91 \\
1,5,15,19 \\
63,94,96,99\end{array}\end{array}$} & \multirow{3}{*}{$\begin{array}{c}\text { No. of spores/ } \\
100 \text { g dry soil } \\
\\
5,5,6,90,41,5 \text {, } \\
46,84\end{array}$} & \multirow{2}{*}{\multicolumn{4}{|c|}{ 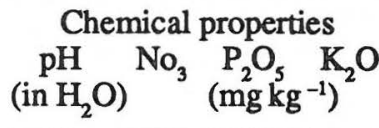 }} \\
\hline & & & & & & & \\
\hline & & & & $\begin{array}{l}6.7 \\
4.7- \\
6.8\end{array}$ & $\begin{array}{l}80 \\
10- \\
22\end{array}$ & $\begin{array}{l}75 \\
14 \\
39\end{array}$ & $\begin{array}{c}81 \\
9- \\
29\end{array}$ \\
\hline \multirow[t]{8}{*}{ Leguminosae } & Glycine hispida & 9 & 5 & 4.8 & 26 & 14 & 9 \\
\hline & Lupinus luteus & 16 & 2 & 5.7 & 35 & 28 & 34 \\
\hline & & 69 & 19 & 6.4 & 83 & 64 & 60 \\
\hline & Medicago sativa & 51 & 21 & 5.8 & 29 & 17 & 9 \\
\hline & Phaseolus vulgaris & 48 & 25 & 6.7 & 71 & 57 & 62 \\
\hline & Trifolium repens & $7,43,57$ & $12,2,1$ & $\begin{array}{l}5.1- \\
6.7\end{array}$ & $\begin{array}{l}29 \\
84\end{array}$ & $\begin{array}{l}15- \\
21\end{array}$ & $\begin{array}{l}10 \\
28\end{array}$ \\
\hline & Vicia faba & 54 & 1 & 5.7 & 34 & 19 & 15 \\
\hline & & 66 & 14 & 5.9 & 30 & 21 & 20 \\
\hline \multirow[t]{2}{*}{ Liliaceae } & Allium porrum & 22 & 3 & 6.1 & 32 & 27 & 39 \\
\hline & Allium schoenoprasum & 67 & 1 & 5.9 & 24 & 17 & 17 \\
\hline Polypodiaceae & Dryopteris filix-mas & 68 & 2 & 4.9 & 18 & 15 & 17 \\
\hline \multirow[t]{8}{*}{ Rosaceae } & Crataegus monogyna & $114,121,140$ & $32,1,18$ & $\begin{array}{l}5.1- \\
6.2\end{array}$ & $\begin{array}{c}19- \\
160\end{array}$ & $\begin{array}{l}20- \\
35\end{array}$ & $\begin{array}{l}17- \\
30\end{array}$ \\
\hline & Fragaria vesca & $20,42,53$ & $22,3,4$ & $\begin{array}{l}4.3- \\
5.9\end{array}$ & $\begin{array}{l}31- \\
48\end{array}$ & $\begin{array}{l}14 \\
25\end{array}$ & $\begin{array}{l}18- \\
21\end{array}$ \\
\hline & Malus domestica & 92 & 5 & 5.7 & 74 & 26 & 12 \\
\hline & Malus $\times$ purpurea & 12 & 38 & 5.1 & 14 & 17 & 8 \\
\hline & Prunus domestica & 74 & 118 & 5.2 & 24 & 18 & 17 \\
\hline & Prunus serrulata & 6 & 47 & 4.9 & 14 & 17 & 12 \\
\hline & Rosa canina & $119,128,138$ & $20,3,4$ & $\begin{array}{l}3.8- \\
6.7\end{array}$ & $\begin{array}{l}38- \\
66\end{array}$ & $\begin{array}{c}6- \\
20\end{array}$ & $\begin{array}{l}14 \\
59\end{array}$ \\
\hline & Rubus idaeus & 120 & 8 & 6.5 & 19 & 12 & 26 \\
\hline Salicaceae & Populus alba & 86 & 28 & 5.7 & 22 & 18 & 12 \\
\hline \multirow[t]{3}{*}{ Solanaceae } & Nicotiana tabacum & 72 & 6 & 4.5 & 22 & 11 & 6 \\
\hline & & 103 & 48 & 5.2 & 73 & 13 & 24 \\
\hline & Solanum tuberosum & 59 & 4 & 5.1 & 45 & 22 & 19 \\
\hline \multirow[t]{4}{*}{ Umbelliferae } & Anthriscus sylvestris & 14 & 28 & 5.2 & 18 & 15 & 12 \\
\hline & & 71 & 12 & 4.1 & 51 & 12 & 21 \\
\hline & Apium graveolens & 23 & 1 & 5.8 & 32 & 18 & 15 \\
\hline & Eryngium maritimum & 33 & 5 & 4.8 & 11 & 9 & 12 \\
\hline
\end{tabular}

decided to re-examine all my specimens of this species and other collections of the Endogonaceae consisting of spore populations obtained from single soil samples. Altogether 152 such collections were re-ex- amined and 48 of the earlier determinations were found to be doubtful or incorrect. The spores from these collections mainly belong to $G$. deserticola, and in addition to $G$. heterosporum Smith \& Schenck and 
Table 5. Frequency of occurrence of Glomus occultum in Poland and chemical properties of soils from which this species was isolated.

\begin{tabular}{|c|c|c|c|c|c|c|c|}
\hline \multirow{3}{*}{$\begin{array}{l}\text { Plant family } \\
\text { Cupressaceae }\end{array}$} & \multirow{3}{*}{$\begin{array}{l}\text { Plant species } \\
\text { Thuja occidentalis }\end{array}$} & \multirow{2}{*}{$\begin{array}{l}\text { No. of soil sample } \\
\text { (see Fig. 23) }\end{array}$} & \multirow{3}{*}{$\begin{array}{l}\text { No. of spores/ } \\
100 \mathrm{~g} \text { dry soil } \\
44\end{array}$} & \multicolumn{4}{|c|}{ Chemical properties } \\
\hline & & & & $\underset{\text { (in } \mathrm{H}_{2}}{\mathrm{pH}}$ & $\mathrm{No}_{3}$ & $\begin{array}{l}\mathrm{P}_{2} \mathrm{O}_{5} \\
\text { (mg k }\end{array}$ & $\underset{-1}{\mathrm{~K}_{2} \mathrm{O}}$ \\
\hline & & 77 & & 5.7 & 24 & 17 & 15 \\
\hline \multirow[t]{2}{*}{ Gramineae } & Calamagrostis arundinacea & 89 & 2 & 4.8 & 21 & 16 & 14 \\
\hline & Triticum aestivum & 58 & 1 & 6.7 & 71 & 24 & 28 \\
\hline Leguminosae & Trifolium repens & 43 & 25 & 6.7 & 84 & 21 & 28 \\
\hline \multirow[t]{4}{*}{ Rosaceae } & Crataegus monogyna & 114 & 2 & 6.2 & 160 & 22 & 31 \\
\hline & & 117 & 1 & 5.0 & 42 & 15 & 25 \\
\hline & Rosa canina & 93 & 9 & 4.5 & 45 & 18 & 17 \\
\hline & & 138 & 1 & 6.7 & 66 & 20 & 59 \\
\hline
\end{tabular}

S. rubiformis, and possibly to some other little known or unknown species. G. fasciculatum spores were found in 87 soil samples (Table 4, Fig. 24). They most often occurred singly in the soil, though samples nos. 29, 37, 58, 74, 75, 82 and 104 mainly contained sporocarps. The spore densities ranged from 1 to 689 per $100 \mathrm{~g}$ dry soil, and the relative densities from 0.3 to $89.6 \%(\overline{\mathrm{x}}=19.4 \%)$. There was no significant correlation between soil $\mathrm{pH}$ and nutrients $(N, P, K)$ and the abundance of spores of this species.

\section{Material examined}

See Table 4; specimens deposited: 155 and 1037-1044 (DPP).

\section{Glomus occultum Walker}

According to Walker (1982), G. occultum spores are hyaline to white, $15-100 \times 20-120 \mu \mathrm{m}$, with $1-3$ walls, of which (when 3-walled) the outermost one sloughs with age, the middle is a very thin $(<1 \mu \mathrm{m})$ unit wall (Walker 1983), and the innermost wall is usually composed of two laminations. Morton's (1985) collections contained only 3-walled spores with a rarely sloughing outermost wall. Morton stated that the two innermost walls form a wall group rather than a single, laminated wall, since both walls separate near the subtending hypha.

The Polish collections usually have 3-walled spores, sometimes with an additional layer of debris (Figs. 18, 19). The inner two walls are usually sepa- rated near the subtending hypha, but they are adherent at some distance from this hypha, forming a wall group. No 1-walled spores were observed. There are also spores with an additional, very thin and rigid wall, which separates from the inner ones and usually fractures under the pressure of a cover glass (Figs. 20,21). In fact, it is probably an evanescent wall of the kind described by Walker (1982), who (Walker 1983) stressed that evanescent walls can be incorrectly identified as unit walls, especially in youth. The other features correspond with the abovementioned descriptions.

G. occultum is probably globally widespread. The countries in which it has been found include the U.S.A., the Netherlands, England (Walker 1982, Miller et al. 1985, Morton 1985) and Italy (Puppi et al. 1986).

In Poland this species was found in 8 soil samples taken from under cultivated and natural plants (Table 5, Fig. 23). Its spore densities ranged from 1 to 44 per $100 \mathrm{~g}$ dry soil, and the relative densities ranged from 0.4 to $13.9 \%$ (av. $6.2 \%$ ). The species is new to Poland.

\section{Material examined}

See Table 5; specimens deposited: 156-218 (DPP).

Acknowledgements. I wish to express my sincere thanks to the editor, Dr. M. Hărkőnen, and the referee, Dr. S.M. Berch (Canada), for their kind reception and careful revision of this article, particularly for constructive criticism and valuable suggestions. 


\section{References}

Becker, W.N. \& Gerdemann, J.W. 1977: Glomus etunicatum sp. nov. - Mycotaxon 6:29-32.

Błaszkowski, J. 1989: Z badá nad wystepowaniem Endogonaceae w Polsce. - Biul. Lubel. Tow. Nauk (in press).

Bloss, H.E. \& Walker, C. 1987: Some endogonaceous mycorrhizal fungi of the Santa Catalina Mountains in Arizona. - Mycologia 79:649-654.

Dalpé, Y., Granger, R.L. \& Furlan, V. 1986: Abondance relative et diversité des Endogonacées dans un sol de verger du Québec. - Canadian J. Bot. 64:912-917.

Hetrick, B.A.D. \& Bloom, J. 1983: Vesicular-arbuscular mycorrhizal fungi associated with native tall grass prairie and cultivated winter wheat. - Canadian J. Bot. 61:2140-2146.

Koske, R.E. 1985: Glomus aggregatum emended: a distinct taxon in the Glomus fasciculatum complex. - Mycologia 77:619-630.

Koske, R.E. 1987: Distribution of VA mycornhizal fungi along a latitudinal temperature gradient. - Mycologia 79:55-68.

Miller, D.D., Domoto, P.A. \& Walker, C. 1985: Mycorrhizal fungi at eighteen apple rootstock plantings in the United States. - New Phytol. 100:379-391.

Morton, J.B. 1985: Variation in mycorrhizal and spore morphology of Glomus occultum and Glomus diaphanum as influenced by plant host and soil environment. Mycologia 77:192-204.

Morton, J.B. 1986: Three new species of Acaulospora (Endogonaceae) from high aluminium, low pH soils in West Virginia. - Mycologia 78:641-648.

Morton, J.B. 1986: Effects of mountants and fixatives of wall structure and Melzer's reaction in spores of two Acaulospora species (Endogonaceae). - Mycologia 78:787-794.

Puppi, G., Chiapperi, F., Tabacchini, P., Sanvito, A. \& Carpigo, F. 1986: Endogonaceae del litorale tirrenico. - Micol. Italiana 2:7-14.

Schenck, N.C. \& Smith, G.S. 1981: Distribution and occurrence of vesicular-arbuscular mycorrhizal fungi on Florida agricultural crops. - Soil Crop Sci. Florida, Proc. 40:171-175.

Schenck, N.C. \& Smith, G.S. 1982: Additional new and unreported species of mycorrhizal fungi (Endogonaceae) from Florida. - Mycologia 74:77-92.

Sylvia, D.M. 1986: Spatial and temporal distribution of vesicular-arbuscular mycorrhizal fungi associated with Uniola paniculata in Florida foredunes. - Mycologia 78:728-734.

Walker, C. 1982: Species in the Endogonaceae: a new species (Glomus occultum) and a new combination (Glomus geosporum). - Mycotaxon 15:49-61.

Walker, C. 1983: Taxonomic concepts in the Endogonaceae: spore wall characteristics in species descriptions. - Mycotaxon 18:443-445.

Walker, C. \& Koske, R.E. 1987: Taxonomic concepts in the Endogonaceae 4. Glomus fasciculatum redescribed. - Mycotaxon 30:253-262.

Zak, J.C., Danielson, R.M. \& Parkinson, D. 1982: Mycorrhizal fungal spore numbers and species occurrence in two amended mine spoils in Alberta, Canada. - Mycologia 74:785-792.

Received on 15 January 1989 